\title{
Muds of the Clyde Sea Area. II. Bacterial Content.
}

\author{
By
}

Blodwen Lloyd, M.Sc., Ph.D.,

From the Dept. of Bacteriology and Botany, Royal Technical College, Glasgow, and the Marine Biological Station, Millport.

With 2 Figures in the Text.

\section{INTRODUCTION.}

An important factor in the economy of the sea is the presence of bacteria, which are found not only in the sea-water itself, but in the mud and sand of the sea bottom. The parts of the sea which are most important biologically are (i.) the upper twenty metres of water in these latitudes, and (ii.) the uppermost layer of the sea floor in regions where the water is less than a few hundred metres deep. The first is of interest as the zone inhabited at the proper season by autotrophic organisms, chiefly phytoplankton. It is here that the products of photosynthesis are largely formed; upon these heterotrophic life in the sea is ultimately dependent. Except in shallow water, there is insufficient light at the sea bottom for photosynthesis, and the organisms inhabiting the sea floor are of necessity heterotrophic. These organisms, among which are protozoa and the majority of bacteria, derive their foodstuffs directly or indirectly from the already organised proteins and carbohydrates of dead organic matter accumulated on the sea floor. The bacteria found in this zone include the following representatives of different physiological groups :-

(i.) Simple heterotrophs, which can utilise the proteins of dead organisms, and which liberate ammonia as waste metabolite.

(ii.) Nitrifying organisms of the two types, (a) those which oxidise ammonia to nitrite, and (b) those which oxidise nitrite to nitrate (14). These bacteria thus assist in the regeneration of nitrate from ammonia. This is important, because although ammonium-nitrogen can be utilised by some algæ and by higher plants, nitrate-nitrogen is in general more readily assimilated by autotrophic plants. Now the low concentration of nitrate is a limiting factor to plant growth in the sea, so it is desirable to know what bacterial changes in the sea may result in its formation.

(iii.) Denitrifying bacteria. These are simple heterotrophs with a special mechanism for reducing nitrate and nitrite to elementary nitrogen, the oxygen thus liberated being used for respiration (see p. 762). 
(iv.) Nitrogen-fixing bacteria, which fix elementary nitrogen by synthesising nitrogenous compounds, possibly ammonia. These have been isolated from algal slime along the coast-line $(\mathbf{5}, \mathbf{6})$, but not from true bottom deposits.

(v.) Sulphur bacteria, which oxidise hydrogen sulphide to free sulphur (16).

The physiological importance of these and other groups will naturally depend upon their numbers, and accordingly the experimental work described below was undertaken (i.) to determine the approximate numbers of bacteria present in samples taken from different types of bottom deposits in the Clyde Sea Area, and (ii.) to make a preliminary investigation into the different types of micro-organisms found.

\section{HisTORICAL.}

The earliest record of the bacteria in marine mud is that of Russel (13), who noted that there were many more micro-organisms in the mud than in the supernatant water. Drew (2) found that the exceptionally high bacterial content of shallow coastal waters in the tropics was due to the fact that the mud flats below were unusually rich in bacteria. These appear to be the only general records of mud bacteria.

Other workers have studied special groups of organisms isolated from marine muds. Nitrifying bacteria of both types were isolated by Thomsen (14) at Kiel from bottom deposits close to the shore. According to Issatchenko (4), nitrate-forming bacteria are found in northern seas in bobtom deposits, but their number depends on the nature of the sea bottom; he found that they were absent from black muds, present in clay deposits, and more abundant in calcareous sandy deposits.

\section{Experimental.}

\section{(a) The Area Investigated.}

The samples examined were all from the Clyde Sea Area, a brief description of which is given by Marshall and Orr (12); the stations used for mud sampling are described by Moore $(\mathbf{9}, \mathbf{1 0})$. The bottom deposits are chiefly muds, with some sands; these are classified into four types by Moore (10), and stations representative of each of these four types were selected for bacteriological analysis as under :-
(i.) Loch-head Type: Station 10, Loch Striven Head. Depth $24 \mathrm{~m}$.
(ii.) Mid-loch Type: Station 11, Clapochlar. Depth $73 \mathrm{~m}$. 
(iii.) Deep-water Type: Station 7B, Garroch-Corrie.

Depth $166 \mathrm{~m}$.

(iv.) Sandy Type: Station 1B, Kames Bay.

Depth $25 \mathrm{~m}$.

\section{(b) Sampling.}

The samples were obtained by means of the apparatus described by Moore and Neill (11). The sampling tube is a cylinder which is sent down open at both ends; thus the water through which it passes streams through the tube and may deposit bacteria on the inside of the glass tube. However, any error thus introduced is negligible, since (i.) it appears that there is practically no streaming of mud up the sides of the glass tube when the sample is pushed through, (ii.) the number of bacteria in the muds is very much higher than that in the water above, and (iii.) the sub-samples. were taken from the centre of the core, which had not been in contact with the glass.

\section{(c) Laboratory Technique.}

The mud samples were transported ashore in the sampling tubes. They were taken below deck in order to keep them cool during the interval between sampling and examination, and they were kept in the dark by means of cardboard sheaths. The time interval between sampling and plating depended on the distance of the sampling station from the laboratory, and varied from half an hour to four hours. On arrival at the laboratory the cylindrical tube was marked off into centimetre lengths, and at selected intervals two sub-samples $(a)$ and $(b)$ were taken from the mud. One sub-sample was used for determination of the interstitial water, and the second was used for estimating the bacterial content.

This portion of the work was carried out in conjunction with Mr. Moore, and the author wishes to acknowledge his kindness in taking the samples, in dividing them into sub-samples, and in determining the amount of interstitial water present in each sub-sample.

Sub-sample $(a)$ was placed in a tared watch glass and weighed; it was. then dried to constant weight at $100^{\circ} \mathrm{C}$. The difference between the first and the final readings gave the total amount of contained water. From these the figures the amount of water contained in sub-sample $(b)$ was calculated. Sub-sample $(b)$ was placed in a tared sterile Erlenmeyer flask and weighed; filtered sea-water, sterilised by autoclaving for 30 minutes at $30 \mathrm{lbs}$. pressure, was then added to make up a volume of 100 c.c. ; the pipettes used were sterilised by heating to $150^{\circ} \mathrm{C}$. for 30 minutes. The whole was then shaken very thoroughly to disperse the constituent mud particles. In the first series of dilutions (Station 7B, $14 / 4 / 30$ and Station 1B, 10/4/30), lead shot was used to facilitate the 
breaking up of the mud. The use of lead shot was then discontinued, on account of the toxic action of metals on most bacteria. It was difficult to disperse the mud particles in sub-samples from the lower layers of mud, which contained less interstitial water.

The diluted sample was then plated out on agar and on gelatine according to the procedure previously described by the writer ( $\mathbf{7})$. Four agar cultures and four gelatine cultures were made, a known volume of the diluted sub-sample being added. In the first samples examined, the amounts of inoculum were 1.0 c.c., 1.0 c.c., 0.5 c.c., and 0.5 c.c., but it was found that the colonies which developed were too crowded for convenient counting, and in the later work the following amounts were used : $0 \cdot 5$ c.c., $0 \cdot 5$ c.c., $0 \cdot 1$ c.c., and $0 \cdot 1$ c.c.

The plates were incubated at room temperature $\left(15^{\circ} \mathrm{C}\right.$.) for five days, and then the bacterial colonies visible to the naked eye were counted. Tables I-IV give the results of the counts ; from these the average number of bacteria per c.c. in each diluted sub-sample was calculated. From this average the number per gram of dry mud was calculated approximately to the nearest thousand.

In estimating the bacterial content of mud the following difficulties occur :-

(i.) The relative amounts of water and of solid matter in sub-samples from different depths in any one series vary very much. The bacteria are present both on the particles and in the interstitial water, but since the organic matter in the mud is the source of their food supply, they will naturally be more densely crowded on the solid particles. It was decided to follow the procedure adopted in soil bacteriology (15), and to estimate the number per gram of dry mud.

(ii.) Some bacteria, such as the nitrogen-fixing bacteria and the nitrifying bacteria, do not grow readily on ordinary culture media, and the figures given below therefore do not include these.

(iii.) Slow-growing forms, such as certain Spirilla, form very small "pin-point" colonies, which are not easily seen with the naked eye when counts are made. For these reasons the bacterial content is probably underestimated.

The numerical work was supplemented by some descriptive and diagnostic study of the species isolated; for this the ordinary bacteriological routine technique was adopted. In the course of this work many hundreds of different strains were isolated. Only a few of these could be identified as known species, and of the many unknown forms, only a few were studied in any detail. 
TABLE I.

Estimations of Bacterial Content of Mud Samples, Station 10, Loch Striven Head,

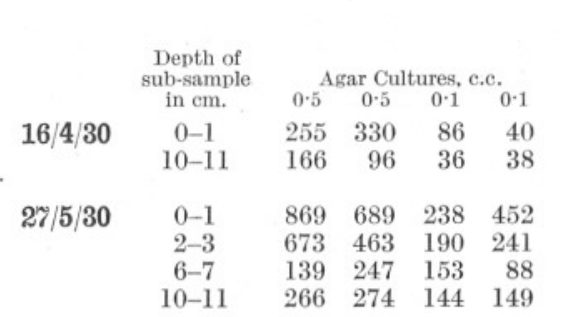

$10-11 \quad 266 \quad 274 \quad 144 \quad 149$

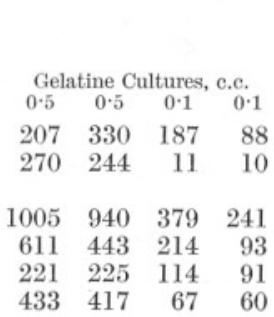

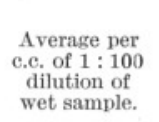

dilution of
wet sample.

635

362

2005

1219

532
754

Wt. of wet
sample in $\mathrm{gm}$.
1.10
0.84

2.47
2.97
1.72
1.55

No. of bac-
teria in

teria in
thousands

thousands
per gm. of

wet mud.

Wh of bacteria in. of dry
ample in gm.
gm. of dry mud.

.

$\begin{array}{rcrrrr}16 / 4 / 30 & 0-1 & 158 & 186 & 39 & 38 \\ & 2-3 & 244 & 298 & 192 & 176 \\ & 10-11 & 205 & 148 & - & 53 \\ & 25-26 & 107 & 162 & 37 & 29 \\ 27 / 5 / 30 & 0-1 & 576 & 684 & 226 & 139 \\ & 2-3 & 596 & 517 & 241 & 203 \\ & 10-11 & 324 & 237 & 84 & 118 \\ & 24-25 & 153 & 250 & 188 & 214\end{array}$

$\begin{array}{rrrrrr}285 & 226 & 29 & 46 & 419 & 0 \cdot 86 \\ 607 & 641 & 220 & 57 & 1014 & 1 \cdot 88 \\ 263 & 323 & 31 & 26 & 456 & 1 \cdot 00 \\ 195 & 146 & 51 & 45 & 321 & 1 \cdot 06 \\ & & & & & \\ 431 & 244 & 148 & 95 & 1059 & 2 \cdot 70 \\ * & 507 & 295 & 126 & 1307 & 2 \cdot 13 \\ 326 & 518 & 74 & 38 & 716 & 1 \cdot 28 \\ 374 & 360 & 83 & 116 & 724 & 1 \cdot 92\end{array}$

49
54
46
30
39
61
56
38

* Colonies too crowded for counting. 
TABLE III.

Estimations of Bacterial Content of Mud Samples.

Station 7B.

\begin{tabular}{|c|c|c|c|c|c|}
\hline \multirow{4}{*}{$14 / 4 / 30$} & $\begin{array}{l}\text { Depth of } \\
\text { sub-sample } \\
\text { in } \mathrm{cm} \text {. }\end{array}$ & \multicolumn{4}{|c|}{$\begin{array}{l}\text { Agar Cultures, c.c. } \\
{ }_{1.0} \\
0.0\end{array}$} \\
\hline & $0-1$ & 582 & 448 & 306 & 0 \\
\hline & $10-11$ & 434 & 547 & 230 & 56 \\
\hline & $27-28$ & 215 & 187 & 128 & 9 \\
\hline \multirow{11}{*}{$3 / 6 / 30$} & $\begin{array}{c}\text { Depth of } \\
\text { sub-sample }\end{array}$ & \multicolumn{4}{|c|}{ Agar Cultures, c. } \\
\hline & in $\mathrm{cm}$. & 0.5 & 0.5 & $0 \cdot 1$ & $0 \cdot 1$ \\
\hline & $0-1$ & 147 & 29 & 22 & 43 \\
\hline & $1-2$ & 72 & 62 & 34 & 29 \\
\hline & $2-3$ & 59 & 25 & 21 & 25 \\
\hline & $3-4$ & 40 & 27 & 31 & 38 \\
\hline & $4-5$ & 87 & 71 & 49 & 70 \\
\hline & $6-7$ & 33 & 17 & 18 & 60 \\
\hline & $12-13$ & 24 & 44 & 33 & 45 \\
\hline & $20-21$ & 27 & 47 & 34 & 50 \\
\hline & $29-30$ & 41 & 44 & 39 & 31 \\
\hline \multirow{4}{*}{$10 / 4 / 30$} & $\begin{array}{c}\text { Depth of } \\
\text { sub-sample }\end{array}$ & \multicolumn{4}{|c|}{ Agar Cultures, c.c. } \\
\hline & $\begin{array}{l}\text { in } \mathrm{em} . \\
0-1\end{array}$ & $\begin{array}{l}0 \\
*\end{array}$ & $\begin{array}{r}1.0 \\
*\end{array}$ & $\begin{array}{c}0.5 \\
328\end{array}$ & $\begin{array}{c}0 \cdot 1 \\
103\end{array}$ \\
\hline & $5-6$ & 297 & 372 & 102 & 59 \\
\hline & $10-11$ & $*$ & * & 120 & 35 \\
\hline \multirow{6}{*}{$27 / 5 / 30$} & $\begin{array}{l}\text { Depth of } \\
\text { sub-sample }\end{array}$ & \multicolumn{4}{|c|}{ Agar Cultures, } \\
\hline & in $\mathrm{cm}$. & 0.5 & 0.5 & $0 \cdot 1$ & $0 \cdot 1$ \\
\hline & $0-1$ & 334 & 343 & 105 & 111 \\
\hline & $2-3$ & 362 & 418 & 154 & 219 \\
\hline & $6-7$ & 301 & - & 151 & 205 \\
\hline & $10-11$ & 418 & - & 93 & 70 \\
\hline
\end{tabular}

\begin{tabular}{rrrr}
\multicolumn{6}{c}{ Gelatine Cultures, c.c. } \\
$1 \cdot 0$ & $1 \cdot 0$ & $\cdot 05$ & $0 \cdot 1$ \\
743 & 585 & 370 & 48 \\
353 & 432 & 195 & 18 \\
355 & 312 & 239 & 12 \\
\multicolumn{6}{c}{} \\
Gelatine Cultures, c.c. \\
$0 \cdot 5$ & $0 \cdot 5$ & $0 \cdot 1$ & $0 \cdot$ \\
119 & 137 & 198 & 145 \\
133 & 37 & - & 108 \\
122 & 134 & 102 & 155 \\
81 & - & 77 & 110 \\
53 & 57 & 71 & 58 \\
96 & 129 & 81 & 53 \\
$*$ & $*$ & 114 & 101 \\
124 & 119 & 84 & 47 \\
$*$ & 185 & 46 & 115 \\
& & &
\end{tabular}

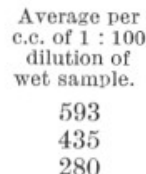
Wt. of wet

No. of bac-

thousands

per gm. of

of dry in thousands pea sample in $\mathrm{gm}$. $\mathrm{gm}$. of dry mud.

$2 \cdot 39$

24

$0 \cdot 73$
$0 \cdot 39$
$0 \cdot 51$

81
110

$1 \cdot 16$

25

$0 \cdot 51$

55

TABLE IV. Station 1B.

Gelatine Cultures, c.c.

$\begin{array}{cccccc}1 \cdot 0 & 1 \cdot 0 & 0.5 & 0 \cdot 1 & & \\ * & * & 622 & 150 & 1002 & 2 \cdot 24 \\ * & * & * & & \end{array}$

$\begin{array}{rrrr}* & * & * & * \\ * & * & 168 & 68\end{array}$

320

1.89

44
17

$0 \cdot 93$

$1 \cdot 16$

107
28

Gelatine Cultures, c.c.

$\begin{array}{rrrr}0.5 & 0 \cdot 5 & 0 \cdot 1 & 0 \cdot 1 \\ 220 & 189 & 131 & 109\end{array}$

$\begin{array}{rrrr}220 & 189 & 131 & 109 \\ * & * & 31 & 87 \\ 539 & - & 181 & 181\end{array}$

642

$0 \cdot 31$

$0 \cdot 30$

$0 \cdot 23$

$0 \cdot 31$

$0 \cdot 24$

$0 \cdot 29$
$0 \cdot 32$

$0 \cdot 45$

$466-116 \quad 239$

* Colonies too crowded for counting.

$\begin{array}{lll}33 & 0.91 & 70 \\ 35 & 1.42 & 63 \\ 43 & 1.65 & 69 \\ 32 & 2.11 & 47\end{array}$




\section{RESULTS.}

(a) Quantitative Work.

Station 10, Loch-head Type. In the sample taken on April 16th, the number of bacteria at the surface of the mud was greater than at a depth

No. of bacteria in thousands per gram of dry mud.
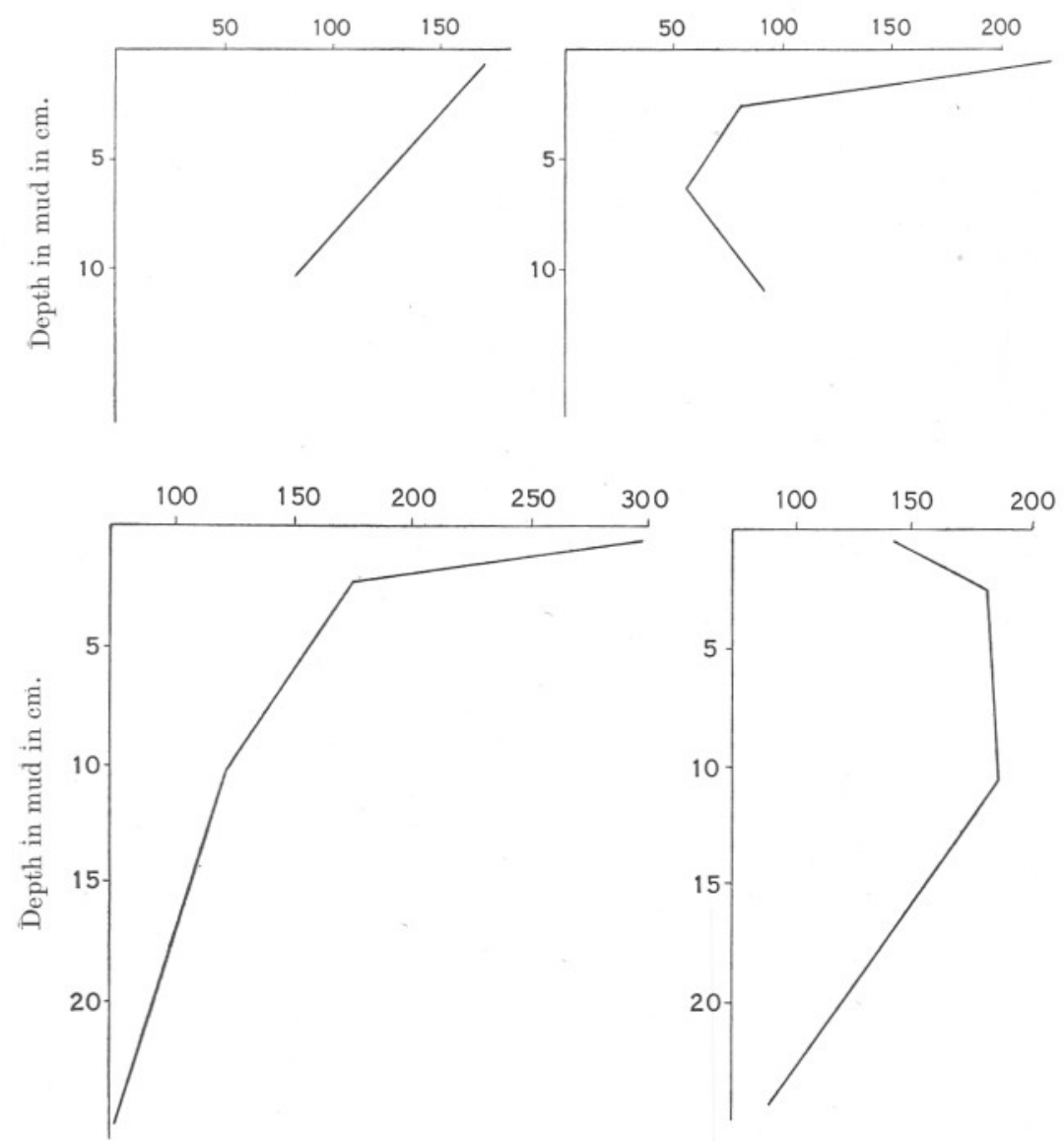

Fig. 1.-Bacterial Content of Marine Muds.

Above, Station 10, 16/4/30 and 27/5/30.

Below, Station 11, 16/4/30 and $27 / 5 / 30$.

of 10-11 cm. (Fig. 1). A second sample, taken on May 27th, showed a surface increase from approximately 170,000 to 227,000 bacteria per gram of dry mud. It showed also a progressive decrease from the surface down to $6-7 \mathrm{~cm}$., and an increase at $10-11 \mathrm{~cm}$; at this depth there was 
relatively little change in the bacterial content in the interval between the first and second sampling (Table I).

Station 11, Mid-loch Type. The first sample taken on April 16th showed a progressive downward decrease in the number of bacteria. After five weeks, a second sample showed a surface decrease from 300,000 to 140,000 , so that there were then fewer bacteria at the surface than at $3-4 \mathrm{~cm}$. and at $10-11 \mathrm{~cm}$. At $24-25 \mathrm{~cm}$. there was a slight increase in numbers (Fig. 1 ; Table II).

Station 7B, Deep-water Type. At this station mud samples from the greatest depth of water were examined. The first sample, taken on April 14th, was marked by higher bacterial content at 10-11 cm. than at the surface : at $27 \mathrm{~cm}$. the numbers were much lower. In order to determine more precisely the vertical variation in bacterial content, the second sample taken on June 3rd was divided into sub-samples at closer intervals. It was found that the number was highest at the surface, but there were two zones, at $3-4 \mathrm{~cm}$. and $12-13 \mathrm{~cm}$. respectively, where the bacterial content increased. Below that level the numbers gradually diminished (Fig. 2, Table III).

Station 1B, Sandy Type. The first sample, taken on April 10th, had a moderately high surface number, but at $5-6 \mathrm{~cm}$. an abnormally low bacterial content-the lowest for any mud examined from this area; there were almost twice as many bacteria per gram at $10-11 \mathrm{~cm}$. as at $5-6 \mathrm{~cm}$. The second sample, taken some six weeks later, showed a great decrease in the number of bacteria at the surface, a slight decrease at 2-3 cm., a slight increase at 6-7 cm., and a decrease at $10-11 \mathrm{~cm}$. (Fig. 2, Table IV).

Summing up these results (see Table V), it is seen in general that the number of bacteria is in most cases greatest at the surface, that there is usually a progressive decrease with increase in depth, that the number fluctuates very widely near the surface of the mud, but that it remains fairly constant at the greatest depths for any given station.

\section{(b) Description of Mud Bacteria.}

In view of the large number of strains isolated, it was not found possible to study the physiology and morphology of all the forms. Certain species with special cultural or physiological characteristics were selected as types for further study, and those organisms having many characters in common were grouped together.

The marine muds examined were found to contain micro-organisms belonging to the following groups :-

(i.) The most frequent organisms were small bacilli similar to those found commonly in sea-water, and resembling the genera Achromobacter 
Bergey and Chromobacterium Bergey (1), which appear to be common in fresh water. These organisms are true water bacteria.

\section{TABLE V.}

Summary of Bacterial Content of Mud. The figures refer to THE NUMBER OF BACTERIA IN THOUSANDS PER GRAM OF DRY MUD, APPROXIMATED TO THE NEAREST THOUSAND.

\begin{tabular}{|c|c|c|c|c|c|c|c|c|}
\hline \multirow{2}{*}{$\begin{array}{l}\text { Depth } \\
\text { in } \mathrm{cm} \text {. }\end{array}$} & \multicolumn{2}{|c|}{ Station 10} & \multicolumn{2}{|c|}{ Station 11.} & \multicolumn{2}{|c|}{ Station $7 \mathrm{~B}$. } & \multicolumn{2}{|c|}{ Station lв. } \\
\hline & $16 / 4 / 30$ & $27 / 5 / 30$ & $16 / 4 / 30$ & $27 / 5 / 30$ & $14 / 4 / 30$ & $3 / 6 / 30$ & $10 / 4 / 30$ & $27 / 5 / 30$ \\
\hline $0-1$ & 171 & 227 & 300 & 140 & 81 & 113 & 107 & 70 \\
\hline $1-2$ & & & & & & 69 & & \\
\hline $2-3$ & & 81 & 175 & 180 & & 81 & & 63 \\
\hline $3-4$ & & & & & & 92 & & \\
\hline $4-5$ & & & & & & 69 & & \\
\hline $5-6$ & & & & & & & 28 & \\
\hline $6-7$ & & 57 & & & & 84 & & 69 \\
\hline 10-11 & 84 & 91 & 120 & 184 & 110 & & 46 & 47 \\
\hline $12-13$ & & & & & & 89 & & \\
\hline $20-21$ & & & & & & 69 & & \\
\hline $24-25$ & & & & 87 & & & & \\
\hline $25-26$ & & & 73 & & & & & \\
\hline $27-28$ & & & & & 55 & & & \\
\hline $29-30$ & & & & & & 58 & & \\
\hline
\end{tabular}

Morphologically, they are non-sporing and Gram-negative, and may be motile or non-motile. On agar they form moist, raised, more or less circular colonies similar to those of the colon-typhoid group, but they are usually slower-growing, and they vary in colour from white or cream to yellow or light brown. Physiologically, they were found to be extremely inert. They grow as readily on the ordinary peptone-containing media as on media prepared from fish extract, but they do not form indol from peptone, and do not readily ferment sugars, not even dextrose. They are thus physiologically much less active than terrestrial saprophytic bacteria under the experimental conditions tried; it is of course possible that this group depends for its nutrition, not directly on the tissues of dead marine organisms, but on the simple nitrogenous compounds and carbohydrates dissolved in the water between the mud particles.

The bacteria of this class isolated from the mud samples have low oxygen requirements. The colonies in cultures used for the quantitative work were frequently found growing down into the medium away from the surface. Although they prefer anaerobic cultural conditions, they are facultative ærobes, for after repeated sub-culture they grow equally readily in well aerated parts of the culture medium. Most of these organisms were also able to utilise nitrates as a source of oxygen by reducing the nitrates to nitrites. Some strains carried the reduction a stage further, with evolution of gaseous nitrogen; such denitrifiers were easily recognised because of the ease with which they reduced nitrates to nitrogen even in the 
presence of some free oxygen. The occurrence of denitrification depends not only on the physiological specificity of the organism concerned, but

No. of bacteria in thousands per gram of dry mud.
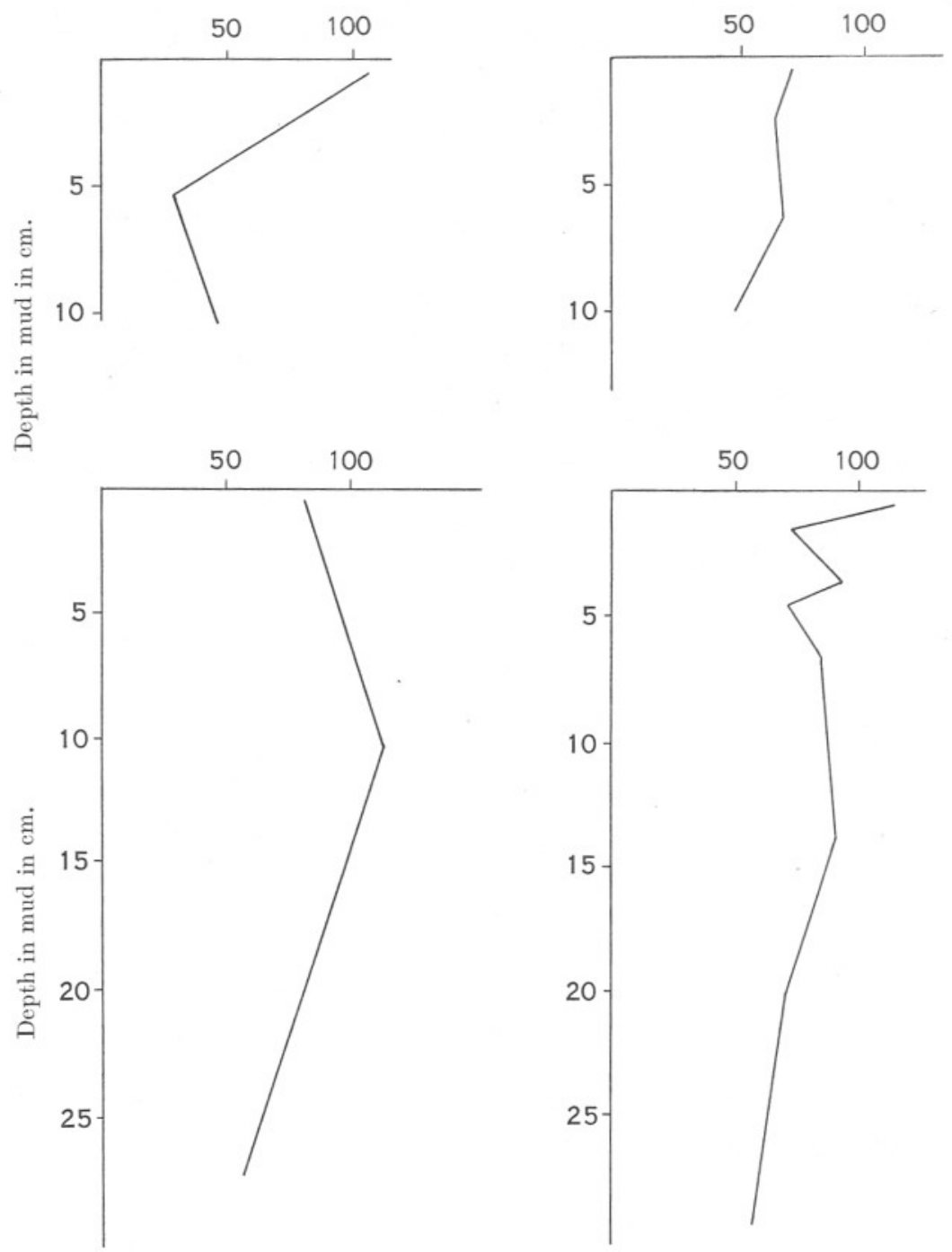

Fig. 2.-Bacterial Content of Marine Muds.

Above, Station $1 B, 10 / 4 / 30$ and $27 / 5 / 30$

Below, Station $7 \mathrm{~B}, 14 / 4 / 30$ and $3 / 6 / 30$.

on such external conditions as temperature, hydrogen ion concentration and initial concentration of nitrate (8). 
(ii.) There occurred in the samples a small proportion of small Gramnegative diplococci and sarcinæ forming cream, yellow or brown colonies. They resembled physiologically the first group, but were morphologically distinct. However, since morphologically bacteria are extremely plastic, it is possible that these are stages in the life history of members of the first group.

(iii.) The second group in order of numerical importance was found to consist of relatively large, spore-forming bacilli similar to the forms common in soil. Microscopically, they are often seen adhering in long chains. Culturally, they are recognised by their white slightly raised colonies, with a matt surface and irregular, dendritic or radiating outline. Physiologically they are more active than the preceding group, for they ferment the common sugars more readily; dextrose and sucrose are commonly attacked by these organisms, and a few are even lactose fermenters. Some strains produced indol from peptone. Under favourable conditions most of the members of this group reduced nitrates to nitrites, and a few reduced nitrates to gaseous nitrogen.

These organisms form a much larger proportion of the bacteria of the muds than of the water above, and they present many resemblances to the common spore-forming soil organisms. It is therefore necessary to consider whether they are species peculiar to marine muds, or whether they are terrigenous. It is not known whether they exist in the mud in the spore state or in the vegetative state.

(iv.) A small proportion of spirilla occurs. They grow only slowly on ordinary media, and the quantitative counts therefore often omit them. They may, however, be found in a mud dilution by first sedimenting the larger mud particles and then centrifuging the suspended micro-organisms and finer mud particles. Large colourless spirilla containing sulphur globules were occasionally found.

\section{DISCUSSION OF RESULTS.}

From the foregoing it is seen that in the Clyde Sea Area the bacterial content of the sea bottom is higher than that of sea-water, even of the water immediately overlying the mud. These results do not necessarily represent the total number of bacteria, since it is highly probable that there are many forms which do not grow on ordinary media, and therefore escape notice. The bacteria of the mud may be affected by the following factors :-

1. Oxygen. It appears that there is no free oxygen in the mud itself, and that oxygen cannot penetrate far below the surface. This has a marked effect upon the distribution of the fauna; Moore has shown elsewhere in this Journal (10) that the oxygen-loving Copepods are restricted to the 
top few centimetres, while the Nematodes, on account of their lower oxygen requirements, can penetrate deeper. It is evident that bacteria are not as a class thus restricted, for they occur in very large numbers even at a depth of $30 \mathrm{~cm}$. These bacteria thus live normally under anærobic conditions, though when cultures are made they grow quite readily in air. It is possible that the muds contain in addition many strict anærobes, whose presence would not be revealed by the ordinary counting technique. However, some preliminary experiments with anærobic cultures made from mud samples did not show any conspicuous anærobe.

The terms "ærobe" and "anærobe" have become increasingly unsatisfactory, since it has been shown that the difference is only one of degree, and that the so-called anærobic bacteria are really organisms which require a low oxygen pressure. Some of these so-called anærobes can utilise combined oxygen; the most important of these are the denitrifying bacteria, which will reduce nitrates, using the oxygen for respiration, and liberating the nitrogen as waste metabolite. There is no direct experimental evidence to show that denitrification occurs in muds.

Hitherto it has been thought that in temperate latitudes the destructive effect of denitrifying bacteria on the nitrate in the sea was negligible, for the following reasons:-(i.) the number of bacteria in the sea-water is relatively low ( $\boldsymbol{(})$, and of these only a certain number are denitrifiers, (ii.) free oxygen is present in sufficient amount to inhibit nitrate-destruction (3), and (iii.) the low temperature prevents denitrification (Gran, 3). The last condition is the only one that applies to the muds, however, for the number of bacteria is extremely high, and the aeration insufficient. The hydrogen ion concentration, the low nitrate concentration, in fact, all conditions except temperature, favour denitrification, so that on theoretical grounds it would appear that loss of nitrate by bacterial action is much more likely to occur here than in the sea-water above.

2. Hydrogen ion concentration. There is a slight downward decrease in $\mathrm{pH}$ value in the muds (10), and there is also a downward decrease in the bacterial content. However, although many micro-organisms are extremely sensitive to changes in hydrogen ion concentration, the range of variation here is too slight to account for the progressive downward decrease in the number of bacteria.

3. Temperature. The rate of multiplication of bacteria increases with temperature up to the optimum for any given species. No data for the temperature of the muds are available, but the low temperature of the bottom waters-from $7^{\circ}$ to $14^{\circ} \mathrm{C}$. in Loch Striven-(12) suggests that the rate of multiplication of bacteria on the sea bottom is limited by this factor.

4. Light Intensity. With increasing depth of overlying water there 
is diminished light intensity at the mud surface. This does not appear to have any effect on the bacterial numbers; there is no apparent relation between the bacterial content at the mud surface and the depth of overlying water. This is confirmed by the fact that at the mud surface the numbers are usually greater. In any case, even the surface of the mud does not receive the short light waves, which are bactericidal in their action.

4. Food Supply. The most important factor affecting bacterial numbers is the amount of available foodstuffs. The chief source of food supply to the mud bacteria is the accumulated dead plankton. This is subject to seasonal variations, for the amount of organic matter deposited on the sea floor depends upon the flora and fauna in the waters above. In the lochs of the Clyde Sea Area the sedimentation of phytoplankton after the spring diatom increase is most important: Moore has shown (10) that this seasonal deposition of diatoms forms well-marked layers in the muds of undisturbed stations.

Such zones would be layers of intense bacterial activity, and would have a much higher bacterial content than the intervening layers; these zones would continue to have a high bacterial content until such time as the food supply was exhausted by the bacteria or other organisms competing for the same food supply. That bacterial zonation occurs in the mud is shown diagrammatically in Figure 2, where at Station 7B there are between the surface and $7 \mathrm{~cm}$. four zones of alternating high and low bacterial content. A more detailed examination of the mud samples would probably show a better correlation between the diatom layers and the zones of high bacterial content, but this so far has not been done ; it would be necessary to take many more samples, in order to ensure that such variations were not chance variations.

Although the surface numbers are high, they are irregular, and do not show any definite relation to the spring increase. For instance, the Lochhead and Mid-loch types show a great difference in bacterial numbers, though at these two places the spring increase is parallel, and of almost equal intensity.

In the deeper mud layers, the food supply is gradually exhausted, but the fauna becomes progressively reduced in numbers downwards, so that bacteria are in all probability the predominant organisms at the greatest depth.

It has already been pointed out that there are great fluctuations in bacterial numbers at the mud surface. These fluctuations would depend partly upon the varying amount of foodstuffs present, and also upon the numbers of organisms such as protozoa which feed upon the bacteria.

The spring diatom increase at all stations was over by April 1st, 1930 ; the accumulation of diatoms at the bottom then follows, the time interval 
depending upon the depth of the water. An accumulation of plankton rain does not necessarily imply a sudden increase in the bacterial population at the bottom. Different species may develop according to the ordinary population curve with an initial lag period, a maximal growth period, and a period of decay due to diminished food supply and accumulation of toxic metabolic products. Different groups of bacteria may follow one another, but there is at present no experimental evidence for this. At the bottom of the sea, however, conditions are complex and cannot accurately be reproduced in the laboratory, so that it is difficult to gain exact knowledge of the growth and physiology of mud bacteria under natural conditions.

In conclusion, the writer wishes to acknowledge the help received from members of the Station staff at Millport.

\section{SUMMARY.}

1. The bacterial content of mud deposits in the Clyde Sea Area has been investigated.

2. The number of bacteria is found to decrease from the surface downwards.

3. The numbers fluctuate very much in the top mud layers, and there is some evidence of bacterial zonation.

4. In the deeper mud layers the bacterial content for any given station is fairly constant.

5. The predominant organisms were found to be water bacteria of the Achromobacter and Chromobacterium type, and large spore-forming bacilli similar to common soil bacteria.

6. The factors affecting the bacterial content of the muds are discussed.

\section{LITERATURE.}

1. Bergey, H. A Manual of Determinative Bacteriology. Baltimore, 1923.

2. Drew, G. H. On the Precipitation of Calcium Carbonate in the Sea by Marine Bacteria, and on the Action of Denitrifying Bacteria in Tropical and Temperate Seas. Journ. Mar. Biol. Assoc., Vol. IX, p. 142., N.S., 1911.

3. Gran, H. H. Studien über Meeresbakterien. Bergens Museums Aarbog., 1901. 
4. Issatchenko, B. Sur la Nitrification dans les mers. Comptes Rend. Acad. Sci., Paris, 1926, CLXXXII, p. 185.

5. Kening, M. Weitere Untersuchungen über stickstoffbindende Bakterien. Wissensch. Meeresunters. Kiel, 1906, IX.

6. Keutner, J. Ueber das Vorkommen und Verbreitung stickstoffbindender Bakterien im Meere. Wissensch. Meeresunters., VIII, 1905.

7. Lloyd, B. Bacteria of the Clyde Sea Area : A Quantitative Investigation. Journ. Mar. Biol. Assoc., N.S., Vol. XVI, p. 879, 1930.

8. Lloyd, B., and Cranston, J. A. Studies in Gas Production by Bacteria. II. Denitrification and Bacterial Growth Phases. Biochem. Journ., 1930, Vol. XXIV, p. 525.

9. Moore, H. B. The Muds of the Clyde Sea Area. I. Phosphate and Nitrogen Contents. Journ. Mar. Biol. Assoc., N.S., Vol. XVI, p. 595, 1930.

10. —. The Muds of the Clyde Sea Area. III. Chemical and Physical Conditions. Journ. Mar. Biol. Assoc., N.S., Vol. XVII, No. 2, p. $325,1931$.

11. Moore, H. B., And Neill, R. G. An Instrument for Sampling Marine Muds. Journ. Mar. Biol. Assoc., N.S., Vol. XVI, p. 595, 1929.

12. Marshall, S. M., And Orr, A. P. The Relation of the Plankton to some Chemical and Physical Factors in the Clyde Sea Area. Journ. Mar. Biol. Assoc., N.S., Vol. XIV, p. 837, 1927.

13. Russel, H. Untersuchungen über in Golf von Neapel lebende Bakterien. Zeitschr. f. Hyg., 1892, XI, p. 165.

14. Thomsen, P. Ueber das Vorkommen von Nitrobakterien im Meere. Wissensch. Meeresunters. Kiel, 1910, XI, p. 1.

15. Waksman, S. A. Methods of the study of the numbers of microorganisms in the soil. Soil Sci., 1922, XIV, p. 283.

16. Wislouch, S. M. Thioploca ingrica, nov. spec. Ber. d. Deutsch. Bot. Ges., 1912, XXX, p. 470. 
| 